\title{
TYGODNIE I WYSTAWY BIBLIJNE - JAKO FORMY APOSTOLATU BIBLIJNEGO
}

Apostolat Biblijny wyraża się'm. in. w takich formach, jak: Godzina Biblijna, Tygodnie i Wystawy Biblijne, wszelkiego rodzaju wykłady poza studium seminaryjnym czy uniwersyteckim - konferencje i kazania o tematyce biblijnej, publikacje prac naukowych i popularno-naukowych o Piśmie św., rozpowszechniahie egzemplarzy Starego i Nowego Przymierza, literatury i periodyków poświęconych zagadnieniom biblijnym.

Dotychczas z mniejszym lub większym powodzeniem realizuje się $\mathrm{u}$ nas wyżej wymienione formy. Cieszy niewątpliwie fakt, iż Godzina Biblijna zdobywa, choć z trudem, prawo obywatelstwa w niektórych diecezjach, zarządzona czy zalecona przez Ordynariuszów. Przyjemnie odnotować prace biblistów o Godzinie Biblijnej publikowane w periodykach biblijnych i diecezjalnych, a także prace kapłanów-duszpasterzów, przeprowadzających Godzinę Biblijną w parafiach.

Mało jednak praktykowane są $u$ nas Tygodnie i Wystawy Biblijne, choć jedna i druga forma jest doniosła i możliwa do przeprowadzenia w każdej parafii. Tym, może zapomnianym formom apostolatu biblijnego poświęcone są następujące sugestie.

\section{Tygodnie Biblijne}

Jak przeprowadzić TB? Najpierw sprawa czasu. Niewątpliwie najlepiej urządzić TB w miesiącu wrześniu, jako że miesiąc ten jest poświęcony w Kościele Katolickim (uroczystość św. Hieronima) Pismu św. jak również z racji, iż pora ta jest w naszych warunkach najbardziej korzystna duszpastersko (intensyfikacja życia po wczasach i urlopach letnich) a nawet klimatycznie (zazwyczaj pogodnie i ciepło). $\mathrm{Na} \mathrm{TB}$ należy poświęcić II tydzień września (w pierwszym dominują sprawy katechizacji, nabożeństwa wstępne, spowiedź, nabożeństwa pierwszopiątkowe), wtedy i sam Tydzień przebiegnie sprawniej i zostanie jeszcze pół miesiąca, okres bardzo przydatny na pogłębienie TB przez Wystawę Biblijną i nawiązywanie do minionego Tygodnia.

TB powinien być zapowiadany już od kilku niedziel w ogloszeniach parafialnych z ambony i w gablotkach, barwnymi i frapującymi afiszami (jeśli to możliwe postarać się o afisze wykonane przez plastyka). W treści ogłoszenia należy podać już hasło TB. Podobnie także na afiszach hasło TB będzie streszczeniem pracy danego roku w parafii w zakresie biblijnym. Rozpoczyna się od hasła podstawowego: „PISMO SW. W KAŻDFJ RODZINIE” lub „PISMO SW. W KAŻDEJ RODZINIE KATOLICKIE.J”!

Pierwszy TB w parafii ma zaakcentować potrzebę posiadania w rodzinie TEJ NAJPIEKNIEJSZEJ KSIEGI SWIATA (Chesterton), następny TB położy nacisk na częstsze czytanie Pisma św., stąd hasło może brzmieć: „PISMO ŚW. CZYTANE W RODZINIE W KAŻDA NIEDZIELE'”! "Hasło roczne opracowuje się w zależności od potrzeb lokalnych. Należy je potem od czasu do czasu w ciągu roku pzrypominać $\mathrm{z}$ ambony i nawiązywać $\mathrm{w}$ stosownym miejscu $\mathrm{w}$ kazaniu, konferencji stanowej czy lekcji religii z młodzieża.

Jak zawsze, tak i w tym przypadku okazałe musi być otwarcie TB. W parafiach wiejskich, gdzie nie ma Mszy wieczornej, otwarcie TB następuje w niedzielę pod wieczór, w miejskich - raczej w poniedziałek wieczorem, gdyż msza wieczorna w niedzielę ma już swój własny program i trudno przedłużać ją jeszcze specjalnym programem biblijnym. Gdyby jednak zaistniały gdzieś racje szczególne za otwarciem w nie- 
dzielę, należałoby odpowiednio zwięźle połączyć specjalny program 'ГB ze Mszą św. Zasadniczo TB wieczorem przebiega w oderwaniu od Mszy św. i wtedy i tak trwa pełną godzinę, od 18-19 lub od 19-20 (w parafiach wiejskich wcześniej, zależnie od warunków lokalnych). Niezależnie od przebiegu TB wieczorem, można dać wyraz Tygodniowi w rannych nabożeństwach i Mszach św. Niemniej jednak i na wsi i w mieście konieczne są wieczorne nabożeństwa biblijne.

Program wieczornego nabożeństwa biblijnego:

1. Tzw. Intronizacja Pisma św. na ołtarzu - śpiew „Wierzę w Boga”

2. Wykład biblijny (10-15 min.) w ramach danego cyklu

3. Śpiew psalmu (jednego ze znanych z nieszporów)

4. Rozważanie biblijne (homilia, konferencja) ok. 15 minut

5. Śpiew jednego lub dwóch psalmów - taca na zakup Pisma św.

6. Czytanie wybranych tekstów Pisma św.

7. Błogosławieństwo N. Sakarmentem w puszce, ewentualnie Komunia

8. Psalm: Boga nászego

9. Komúnikaty i ewentualnie krótka nauka nowych psalmów.

Podanym punktom programu należy się wyjaśniєnie.

Ogólnie biorąc, program jest tak ułożony, by odbiegał od znanych wiernym nabożeństw, związanych najczęściej z jakąśs litanią, co jak wiemy - jest dosyć stereotypowe, mało ciekawe a nawet nużące. Program nabożeństwa biblijnego musi być atrakcyjny, jeśli ma wpływać zachęcająco na. uczestników i powiększać frekwencję wiernych.

Proponowany program jest już wynikiem doświadczenia i zdaje egzamin. Warto go zatem przeprowadzić, ale można także ten czy inny punkt zmienić, przystosować do warunków lokalnych lub nawet ubogacić w nowe punkty, z czym chętnie zapoznałby się autor tych sugestii i na co uprzejmie oczekuje.

Szczegółowo - do każdego punktu - uwagi były następujące:

Tzw. Intronizacja - to umieszczenie tekstu Pisma św. na ozdobnie nakrytym pulpicie na środku głównego oltarza, tuż przed Tabernakulum, obok dwóch zapalonych świec. Z zakrystii kapłan, poprzeđzony ministrantami, wynosi okazały egzemplarz Pisma św. Kapłan nakryły tuwalnią, obok niego dwóch ministrantów z zapalonymi świecami. Wierni wstają na znak uszanowania i śpiewają ,Wierzę w Boga", wyrażając przez to wiarę $w$ to wszystko, co zawarte jest w Credo a zarazem w Ewangelii. Umieszczenie Pisma św. przed Tabernakulum uwidacznia i zeștawia fakt obecności Chrystusa pod postacią Chleba i Słowa. Intronizacja ta - naturalnie mutatis mutandis - wzorowana jest na praktyce soborowej, o czym zresztą donoszono z Watykanu w czasie pierwszej sesji II Soboru Watykańskiego, a co byı̀ już praktykowane w czasie poprzednich soborów. Intronizacja wraz ze śpiewem Credo i scenerią światła (poza dwoma świecami obok Pisma św. nie zapala się innych świec - te dopiero na błogosławieństwo - ani światła eleitrycznego) robi ogromne wrażenie, wprowadza uczestników od razu we właściwą atmosferę, tak potrzebną do owocnego przeżycia całego nabożeństwa.

Egzemplarz Pisma św. umieszczany na pulpicie powinien być okazały - jeśli to możliwe - zewnętrznie, najpiękniejszy z posiadanych przez kapłana lub pożyczony w parafii, gdyby taki był u kogoś z wiernych. Najlepiej, gdy będzie to Nowe Przymierze, Chrystus w Słowie. Byłoby wskazane użyć do intronizacji jakiś czcigodny, dawno wydany tekst Ewangelii. Zawsze znajdzie się taki tekst w parafii. Daleka analogia, ale - jak wiemy - w czasie obecnego soboru uzyto do intronizacji dawny, sprzed ok. 300 laty kodeks, nazwany ,Urbinate latino 10". 
Po intronizacji wykład, wygłoszony jasno, zrozumiale, przystępnie. Temat wykładu w ramach cyklu. W pierwszym TB należało by poruszyć sprawy zasadnicze, a więc dać podstawową orientację o księgach Pisma św. Starego i Nowego Przymierza. Można by w TB poświęcić np. trzy pierwsze dni Staremu, pozostałe zaś Nowemu Przymierzu, stąd byłyby „,dni SP” i ,dni NP”. Podaję dla przykładu:

Dni Tygodnia Biblijnego:

Temat wykładu:

7 IX - Dzień Starego Przymierza

8 IX -

9 IX -

10 IX -

11 IX -

12 IX -

13 IX -

",
Nowego
,",

",

- Znaczenie Starego Przymierza

- Księgi SP

- Zbawienie ideą centralną SP

- Ewangelie

- Dzieje Apostolskie

- Listy Pawłowe

- Listy katolickie i Apokalipsa

Wykłady biblijne wygłaszaliby, zależnie od mózliwości i zapotrzebowania, kapłani miejscowi lub zaproszeni bibliści. Jeśli to byłoby potrzebne, można by do pomocy użyć tablicy i kredy, nawet epidiaskopu czy filmu. Należałoby także umożliwić uczestnikom notowanie wykładów oraz uwzględnić możliwość zapytania o wyjaśnienie spraw mniej zrozumiałych i niejasnych pod koniec wykładu. Jest to dopuszczalne w kościele, choćby zabranie głosu miało znamiona dyskusji, byle tylko poważnej i rzeczowej.

W następnym TB cykle byłyby bardziej szczegółowe.

Spiew psalmu - jednego ze znanych z nieszporów - pozwala uczestnikom wypocząc myślowo i przygotować się do punktu następnego, którym jest rozważanie biblijne, homilia lub konferencja, zależnie od sytuacji. Jeśli w parafii jest dwóch kapłanów, dobrze będzie, gdy przeprowadzi rozważanie inny kapłan. Ważne jest tylko by rozważanie dało raczej przeżycie duchowe wraz $\mathrm{z}$ postanowieniem ascetycznym do wypełnienia w dniu następnym, a nie tylko wiedze biblijną, co było zadaniem wykładu przede wszystkim. Rozważania te mogłbyby być powiązane $\dot{z}$ omawianą $w$ danym dniu tematyką, na tle treści jakiejś księgi lub odstępu jakiegoś rozdziału. Nie jest to jednak warunek konieczny, rozważania mogą odbiegać zupełnie od tematyki dnia, a nawet nie być ujęte w cykl, lecz występować luźno, każde dla siebie jako całość. Najistotniejsze jest tu tylko to, że ma ono sprowadzić działanie, pobudzić do wykonania jakiegoś zadania w stosunku do siebie czy drugich w dniu następnym, a może i na przyszłość.

Po rozważaniu śpiewa się jeden lub dwa psalmy, tak by w czasie śpiewu można było zebrać tace na kupno Pisma św. dla nowożeńców (daje się je wraz z dedykacją pisaną i ustną przy końcu ceremonii ślubnych przy ołtarzu, jak to wprowadzono w parafii św. Tomasza Apostoła w Sosnowcu) lub książek biblijnych, jeśli jest w parafii Biblioteka Parafialna czy też Biblioteka Biblijna. Trzeba wyraźnie podać cel tej kolekty, wtedy wierni chętniej złożą grosz na takie potrzeby.

$\mathrm{Z}$ kolei następuje czytanie tekstów Pisma św., związanych raczej z tematyką dnia. Do czytania. (okolo 10 minut) zaprasza się mężczyzn, podając im w przeddzień dany odstęp Pisma św. Nalezy zaznaczyć im, żeby czytali wolno, głośno i dobitnie. Jeśli jest mikrofon, pouczyć z jakiej odległości. Naturalnie już $w$ wyborze kandydata do czytania nalej̇y uwzględnić jego postawę moralną i katolicką w parafii oraz jego uzdolnienia głosowe. W ten sposób unika się zbytecznych komentarzy wie:nych, a raczej wywołuje zachwyt, co ułatwia również słuchanie czytanego tekstu i jego zapamiętanie. To zbiorowe czytanie Pisma św. i w do- 
datku przez laikat jest także dobrym dalszym przeżyciem danego dnia w Tygodniu Biblijnym.

Po czytaniu błogosławieństwo N. Sakramentem. Poza wartościami rozumowo-emocjonalnymi nabożeństwa uzyskują uczestnicy tak istołne i cenione błogosławieństwo Chrystusowe. Jeśli jest zwyczaj przyjmowania Komunii św., następuje jej rozdanie przy śpiewie psalmu: Boga naszego i Magnifikat.

Komunikaty, zwłaszcza zachęta do przyprowadzenia ze sobą choćby jednej czy dwóch osób na jutrzejsze nabożeństwo i ewentualnie nauka nowych psalmów - są ostatnim punktem programu nabożeństwa biblijnego wieczorem.

Do tego wieczorowego przebiegu TB dodać można poranne nabożeństwo - jak to już wspomniano. Choć nie wszyscy, z powodu pracy zawodowej, ale może w pewnej części, mogliby uczestnicy wieczornych nabożeństw przeżyć jeszcze Mszę św. dialogowaną czy recytowaną. Mogliby wysłuchać Lekcji i Ewangelii na dany dzień (można równied̀ odczytanie lekcji i Ewangelii włączyć do programu wieczornego, teksty tychże mogłyby służyć do rozważań wieczornych) i poznać pozostałe części zmienne, tworzone $\mathrm{z}$ bogactwem tekstów Pisma św.

W ciągu dnia, gdyby pewnym grupom starczyło czasu, mogłoby odbywać się czytanie Pisma św. zbiorowe po domach. Szczególnie powinno się pamiętać wtedy o chorych i starszych i dla nich zorganizować chętnych do czytania im Pisma św. domowników lub obcych, o ile sami nie byliby w stanie czytać. Osoby te przekazywałyby tym ludziom wiadomości zasłyszane w kościele, ułatwiałyby nabywanie Pisma św. i literatury biblijnej, służyły wyjaśnieniem i uwagami, informowały oy o przebiegu TB (przydatne byłyby choćby maszynowe programy $z$ tematami wykładów, rozważań, czytanych odstępów Pisma św. w efektownych, wykonanych przez plastyka lub uzdolnionego w tym kierunku kogoś innego, okładkach — niezależnie od programu na dużych afiszach przed kościołem).

W ten sposób TB objąłby całą parafię, bo jeszcze jest i młodzież i dzieci, które w ramach nauki religii należałoby zapoznać z TB i w sposób przystępny przedłożyć im pewne zagadnienia. Młodzież natomiast, starszą zwłaszcza, można by zachęcić do brania udziału, choćby w nabożeństwach biblijnych wieczorem.

Zakończenie Tygodnia Biblijnego należałoby urządzić możliwie najuroczyściej, nawet poprosić - jeśli to możliwe - Ordynariusza diecezji lub Biskupa Pomocniczego czy kogoś innego przez co zakończenie zyskałoby na okazałości, a tym samym głębiej utrwaliłoby się w przeżyciach i pamięci wiernych. Byłoby wtedy miejsce na zamknięcie Konkursu Biblijnego, połączone $z$ rozdaniem nagród, a także na otwarcie lub zamknięcie Wystawy Biblijnej, o czym później.

c. d. n.

Sosnowiec

KS. WACEAW CHMIELARSKI 